\title{
Evaluation of the friction force generated by monocristalyne and policristalyne ceramic brackets in sliding mechanics
}

\author{
Roberta Ferreira Pimentel ${ }^{1}$, Roberto Sotto Maior Fortes de Oliveira², Maria das Graças Afonso Miranda Chaves³, \\ Carlos Nelson Elias ${ }^{4}$, Marco Abdo Gravina ${ }^{5}$
}

Objective: To evaluate and compare "in vitro" the maximum friction force generated by three types of esthetic brackets, two types of polycrystalline conventional ceramic brackets (20/40 and $\mathrm{InVu}$ ) and one type of sapphire monocrystalline bracket (Radiance) in dry and artificial saliva wet settings. Also, to evaluate the influence exerted by artificial saliva on the friction forces of those brackets. Methods: Tests were performed in dry and artificial saliva wet setting (Oral Balance) by using an EMIC DL 10000 testing machine, simulating a 2 $\mathrm{mm}$ slide of $0.019 \times 0.025$-in rectangular stainless steel wires over the pre-angulated and pre-torqued (right superior canine, Roth prescription, slot $0.022 \times 0.030$-in) brackets ( $\mathrm{n}=18$ for each bracket). In order to compare groups in dry and wet settings, the ANOVA was used. For comparisons related to the dry versus wet setting, the student $t$ test was used for each group. Results: The results showed that in the absence of saliva the Radiance monocrystalline brackets showed the highest friction coefficients, followed by the $20 / 40$ and the InVu polycrystalline brackets. In tests with artificial saliva, the Radiance and the 20/40 brackets had statistically similar friction coefficients and both were greater than that presented by the InVu brackets. The artificial saliva did not change the maximum friction force of the Radiance brackets, but, for the others (20/40 and $\mathrm{InVu}$ ), an increase of friction was observed in its presence. Conclusion: The InVu brackets showed, in the absence and in the presence of saliva, the lowest friction coefficient.

Keywords: Friction. Orthodontic brackets. In vitro. Biomedical and dental materials. Biomechanics.

Objetivo: avaliar e comparar in vitro as cargas máximas de atrito geradas por três tipos de braquetes estéticos, sendo dois deles cerâmicos policristalinos convencionais (20/40 e InVu) e um monocristalino de safira (Radiance), em ambientes seco e umedecido por saliva artificial. Também avaliar a influência exercida pela saliva artificial sobre as cargas de atrito dos referidos braquetes. Métodos: os ensaios foram realizados em ambiente seco e em ambiente umedecido com saliva artificial em gel (Oral Balance), utilizando uma máquina de ensaios mecânicos (EMIC, modelo DL10000), simulando um deslizamento de $2 \mathrm{~mm}$ de fios retangulares 0,019 ” x 0,025” de aço sobre os braquetes (n = 18, para cada braquete), pré-angulados e pré-torqueados (canino superior direito prescrição Roth, slot 0,022” x 0,030"). Para comparação entre os braquetes, em ambiente seco ou umedecido, utilizou-se a análise de variância; e para a comparação dos braquetes em ambiente seco e umedecido, utilizou-se o teste t para amostras independentes. Resultados: os resultados obtidos indicaram que, na ausência de saliva, os braquetes monocristalinos Radiance demonstraram o maior coeficiente de atrito, seguidos pelos braquetes policristalinos 20/40 e InVu. Nos ensaios realizados em ambiente umedecido, os braquetes Radiance e 20/40 apresentaram coeficientes de atrito estatisticamente semelhantes, e superiores ao apresentado pelos braquetes InVu. A saliva artificial não promoveu alterações na força máxima de atrito para os braquetes Radiance; todavia, para os demais (20/40 e InVu), promoveu aumento significativo nos coeficientes de atrito. Conclusão: os braquetes InVu apresentaram, tanto nos ensaios realizados na ausência, quanto na presença de saliva, os menores coeficientes de atrito, entre os braquetes ensaiados.

Palavras-chave: Fricção. Braquetes ortodônticos. In vitro. Materiais biomédicos e odontológicos. Biomecânica.

" The authors report no commercial, proprietary or financial interest in the products or companies described in this article.

${ }^{1}$ MSc Student in Dental Clinic, UFJF.

${ }^{2}$ Associate Professor of Orthodontics, UFJF.

${ }^{3}$ Associate Professor of Pathology, UFJF.

${ }^{4}$ Associate Professor of Biomaterials, UFF.

${ }^{5}$ Associate Professor of Orthodontics, UFJF.

Submitted: August 21, 2010 - Revised and accepted: January 17, 2012
How to cite this article: Pimentel RF, Oliveira RSMF, Chaves MGAM, Elias $\mathrm{CN}$, Gravina MA. Evaluation of the friction force generated by monocristalyne and policristalyne ceramic brackets in sliding mechanics. Dental Press J Orthod. 2013 Jan-Feb; 18(1):121-7.

Contact address: Marco Abdo Gravina

Av. Barão do Rio Branco, 2595 - Salas 1203 e 1204 - Centro

CEP: 36010-011 - Juiz de Fora/MG - Brazil

E-mail: marcoabdogravina@yahoo.com.br 


\section{INTRODUCTION}

Friction can be defined as a force that is tangent to the common limit of two objects in contact with each other, and which resists the displacement or the imminent displacement of one object against the other. ${ }^{5,13}$

$\mathrm{Begg}^{6}$ argues that the greatest challenges for orthodontists during an orthodontic displacement include: Pain, the difficulty of producing smooth and continuous forces and resistance to dental displacement caused by friction. Stoner ${ }^{30}$ also states that in many cases, when orthodontic mechanics proves itself inefficient, the forces that were applied have likely been dissipated due to friction against brackets, wires and ligatures, which makes it harder to control and magnify the load each tooth receives individually, and favors the so-called reaction forces such as anchorage loss.

Thus, it is extremely important to understand the influence friction exerted on the sliding mechanics of brackets and orthodontic wires, since the application of an optimal force system, through efficient mechanic displacement, is interdependent on the minimization of the frictional forces opposed to the initiation (static friction) and the preservation of dental displacement (dynamic friction). ${ }^{1,8,12,14,24,29}$

There are many factors that contribute to an increased friction load during sliding mechanics such as bracket and wire composition, slot size, wire dimensions and shape, method of ligation, and some intraoral variables such as saliva itself. $1,5,8,10,22,29,33,35$

With a great number of adults seeking orthodontic treatment, esthetic brackets have become very popular. Because these brackets are associated with a greater friction coefficient in sliding mechanics, they could correlate with less efficient dental displacement mechanics when compared to metal brackets. ${ }^{11,14,16,26,31}$ Bishara ${ }^{7}$ reported a $30 \%$ reduction in displacement mechanics during canine retraction when using ceramic brackets compared with stainless steel brackets.

In addition to greater esthetic potential ${ }^{27}$, sapphire monocrystalline ceramic brackets present more polished slot surfaces than traditional polycrystalline brackets, which, according to manufacturers and some authors, ${ }^{15,26,29}$ can provide decreased friction coefficient in sliding mechanics - a favorable factor for more efficient dental displacement.
In light of the recent popularity and acceptance of sapphire monocrystalline brackets and ceramic polycrystalline brackets by both patients and professionals, the objective of this article is to assess and compare in vitro maximum frictional forces produced by conventional ceramic polycrystalline brackets (20/40 and $\mathrm{InVu}$ ) and Radiance sapphire monocrystalline brackets in sliding mechanics on rectangular stainless steel wires (both in dry and artificial saliva wet settings); and, also, assess each bracket separately for whether the presence of saliva could produce any change in the maximum frictional force.

\section{MATERIAL AND METHODS}

Fifty-four pre-angulated and pre-torqued esthetic orthodontic brackets were used with a Roth prescription (maxillary right canine) with a $0.022 \times 0.030$-in slot, and divided into three groups $(\mathrm{n}=6)$ according to the commercial brand, with 18 Radiance (American Orthodontics, Sheboygan, USA) sapphire monocrystalline brackets,18 20/40 (American Orthodontics) ceramic polycrystalline brackets, and $18 \mathrm{InVu}$ (TP Orthodontics, La Porte, USA) ceramic polycrystalline brackets.

For the friction tests, fifty-four (GAC International Inc, Bohemia, USA) 0.019 x 0.025-in rectangular wire segments were used, each approximately $15 \mathrm{~cm}$ long, in addition to the brackets, and were inserted and tied to the bracket slots with esthetic elastomeric silicone ligatures (GAC International Inc., Bohemia, USA). Tests were done in both dry and artificial saliva wet settings. Oral Balance (Biotene, São Paulo, Brazil) artificial saliva gel was used for the wet setting tests, and was evenly and similarly spread with a smooth bristle brush on top of all wire segments, brackets, and bands.

Maximum frictional forces, as produced by sliding the wire segments over the brackets, were determined with an EMIC, model DL10000, universal mechanical test machine by the Instituto Militar de Engenharia (IME), Rio de Janeiro. The test speed was 3 mm sliding per minute.

To carry out the tests, an acrylic device directly coupled to a mechanical test machine was used, wherein the brackets were positioned according to the methodology employed by Nishio et al. ${ }^{23}$ After test specimens were formed (bracket-wire-ligature), 
brackets were glued to the center of individual acrylic cylinders (Fig 1) by using a Super Bonder ${ }^{\circledR}$ (Loctite, ${ }^{\circledR}$ São Paulo, Brazil) universal instant adhesive. These cylinders were positioned and fitted to the center of the acrylic device through two metal rods that were mounted to the device with two bolts. These bolts were tightened so that the metal rods would not exert any type of pressure on the orthodontic wires and would be used only to keep the individual acrylic cylinders and the test specimens positioned in the center of the acrylic device. Two cylinders were positioned around the metal rods, which allowed them to roll during the sliding of the wires so that any external frictional force would be canceled out during the test.

Wire segments were mounted to the mechanical test machine with a metal wire for traction. After assembling the entire test system (Fig 2), the wire was pulled $2 \mathrm{~mm}$ and the maximum frictional force was measured for all test specimens.

Each bracket was tested once, totaling 54 tests with 18 maximum frictional force measurements for each bracket group, nine in a dry setting and nine in a wet setting. The (ANOVA) analysis of variance was used to compare the maximum frictional force within the different bracket groups both in dry or wet settings, whereas the $t$ test was used to compare the bracket's maximum frictional forces for independent samples in dry and wet settings. A confidence interval of $95 \%$ was selected for the statistic tests, where $\mathrm{p} \leq 0.05$ indicates significant differences within groups.

\section{RESULTS}

Tables 1 and 2 show the mean maximum frictional force and the standard deviation for the three groups of brackets calculated through mechanical tests both in a dry and in an artificial saliva wet setting, respectively. Regardless of the type of bracket that was used and the test setting, a low standard deviation was found, making the means both reliable and representative.

Results demonstrated that in the absence of saliva, statistically significant differences were found for all groups ( $\mathrm{p} \leq 0.05$ ), and the highest frictional force was that of Radiance, followed by 20/40 and, finally, by $\mathrm{InVu}$, which had the lowest frictional force in a dry setting.

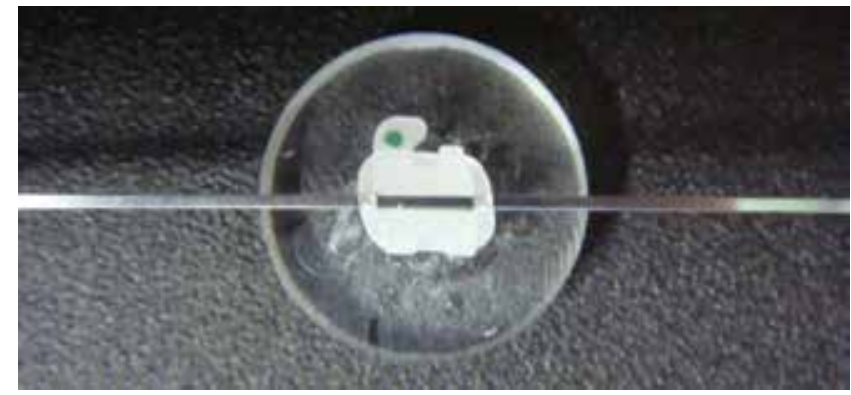

Figure 1 - Preparing test specimen made up of bracket, wire and ligature and fixing it to the acrylic cylinder.

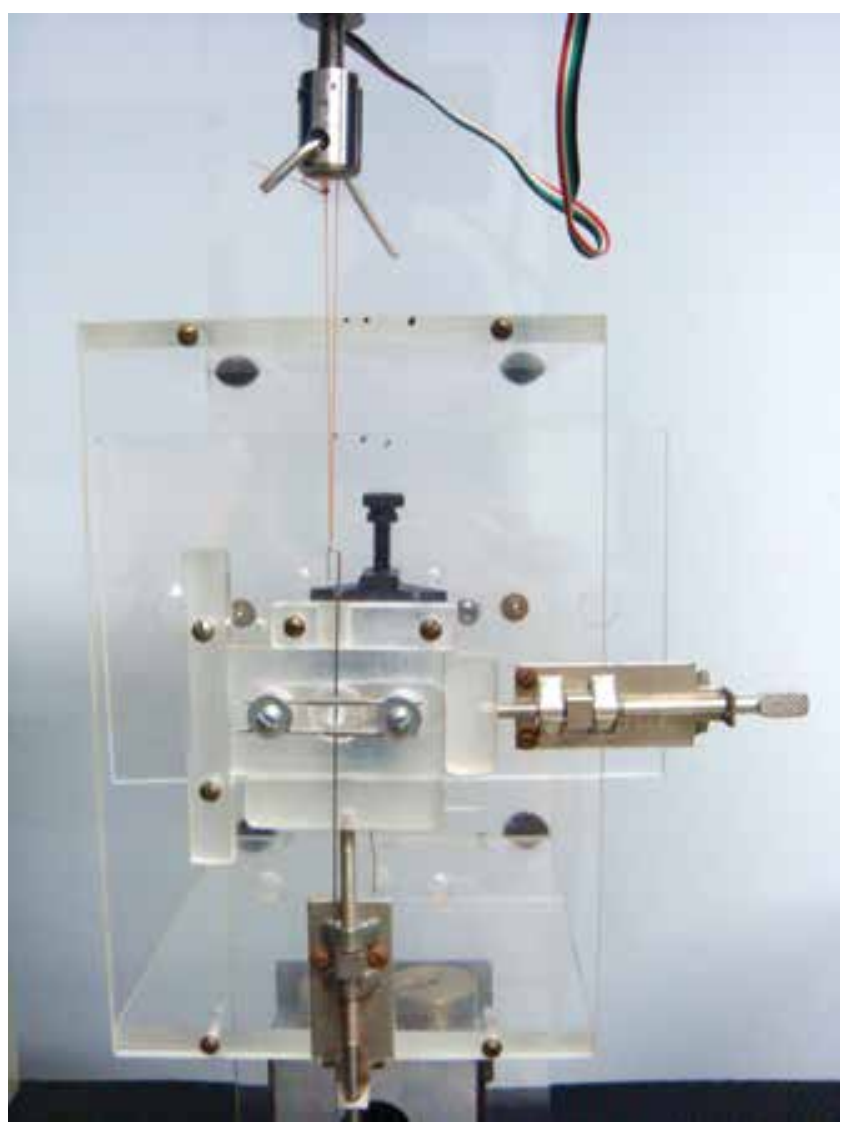

Figure 2 - Completely assembled test system.

For tests done in the presence of saliva, Radiance and 20/40 brackets did not have statistically significant differences between each other $(p=1.000)$. InVu brackets, in turn, had significantly reduced frictional forces compared to the other two groups of brackets $(p=0.000)$.

In order to demonstrate whether the presence of saliva would cause differences in the maximum frictional forces, intergroup $t$ tests were carried out for independent samples. 


\begin{tabular}{|c|c|c|c|}
\hline BRACKET & MAXIMUM FORCE (MEAN) & SD & n \\
\hline Radiance & 216.2 & 21.0 & 9 \\
\hline $20 / 40$ & 193.0 & 15.4 & 9 \\
\hline Invu & 154.0 & 19.5 & 9 \\
\hline
\end{tabular}

${ }^{*} p \leq 0.05$

Table 2 - Mean maximum frictional force and standard deviation for Radiance, 20/40, and InVu brackets for wet setting tests.

\begin{tabular}{cccc}
\hline BRACKET & MAXIMUM FORCE (MEAN) & SD & n \\
\hline Radiance & 208.5 & 2.6 & 9 \\
\hline $20 / 40$ & 207.6 & 13.9 & 9 \\
\hline Invu & 171.7 & 15.2 & 9 \\
\hline
\end{tabular}

${ }^{*} p \leq 0.05$

Variations in the maximum frictional forces for each group of brackets, both in the presence and absence of saliva, are shown in Figure 3.

Results based on statistical analysis demonstrated that with Radiance brackets the presence of saliva did not produce any significant changes in the maximum frictional forces $(p=0.307)$.

When 20/40 brackets were analyzed, the presence of saliva significantly changed the maximum frictional force $(p=0.050)$, which was higher in the presence of saliva (207.6 gf) than in its absence (193 gf).

For InVu brackets, the presence of saliva also produced significant changes $(p=0.047)$ with a significant increase in maximum frictional force (171.7 gf) when compared to the test performed in its absence (154 gf).

\section{DISCUSSION}

As previously cited, there are many factors influencing frictional forces, including: bracket and wire composition, slot size (0.018-in or 0.022-in), orthodontic wire dimensions and shape, ligation method, mechanical test speed, and the presence or absence of saliva. Thus, the methodology used in this study tried to minimize the influence of such variables by keeping slot size, bracket prescription, test speed, orthodontic wire characteristics, and artificial saliva unchanged. This allowed us to compare the maximum frictional force produced by polycrystalline and monocrystalline brackets when tested in the presence and absence of saliva.

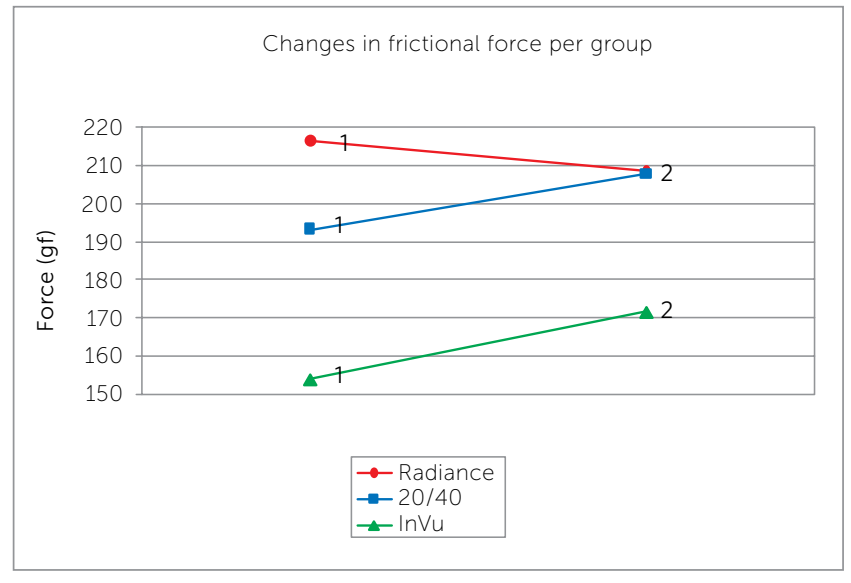

Figure 3 - Changes in (mean) maximum frictional force for each group of brackets when tested in the absence (1) and in the presence (2) of artificial saliva.

When comparing the three types of brackets in a dry setting, significant differences were found in their maximum frictional force, which demonstrates that bracket material influences its friction and corroborates findings by several authors. ${ }^{1,5,10,12,14,29,33,35}$ By contrast, when Kusy and Whitley ${ }^{17}$ evaluated different bracket and wire combinations, they stated that the variable "bracket" did not produce significant differences in the frictional force when compared to stainless steel and alumina brackets.

The sliding of the wires over the brackets could promote wire surface wear, which, according to Tanne et $\mathrm{al},{ }^{31}$ could be greater when using ceramic brackets, therefore increasing the frictional coefficient and hampering displacement. In an attempt to eliminate this variable, this study used a wire segment for each bracket and the same wire area was not pulled more than once. Had this not been done, masked results could have been achieved because with more tests performed on the same wire (same surface), more wear would have been produced, and consequently higher frictional forces would have been generated.

In spite of having a smoother surface, according to their manufacturers and some authors, ${ }^{15,26,29}$ Radiance monocrystalline brackets had a statistically higher friction for the dry setting tests than the other polycrystalline ceramic brackets. This finding is in compliance with results from studies by Sadique et $\mathrm{al}^{28}$ who, by using a similar methodology, compared conventional ceramic and monocrystalline bracket friction through sliding mechanics and found similar results. 
Although brackets have the same prescriptions for this study, the possible differences in the existing angles for the brackets and the wires were cancelled out by using individual acrylic cylinders and eliminating the need for additional precautions such as leaving brackets with a $0^{\circ}$ inclination against the wires. This way, inappropriate bracket positioning over the acrylic cylinders was eliminated when these were rotated. ${ }^{23}$ Although Cha, Kim and Hwang ${ }^{10}$ used a different methodology - due to the fact they carried out static friction tests (the load required for starting displacement), dynamic tests (like this study), and angulated tests between brackets and wires - they found similar results with high frictional forces for sapphire monocrystalline brackets compared to those found during tests of other conventional ceramic brackets.

When compared to the results found in this study, tests performed by Saunders and Kusy ${ }^{29}$ and De Franco, Spiller and Von Fraunhofer ${ }^{11}$ found that polycrystalline and monocrystalline brackets demonstrated similar frictional forces in a dry setting in sliding mechanics over stainless steel, cobaltchrome, nickel-titanium, and beta-titanium wires. Even though they demonstrated such results, they proved the existence of smoother and more polished surfaces in the monocrystalline bracket slots than polycrystalline brackets though the use of scanning electron microscopy. Loftus et $\mathrm{a}^{21}$ corroborated this finding when they emphasized that bracket superficial roughness might not result in significant differences in the frictional force. No scientific papers were found in the literature that demonstrated lower frictional forces for monocrystalline brackets than for polycrystalline brackets.

When brackets were tested in the presence of saliva, Radiance and 20/40 brackets were found to have statistically similar frictional forces, whereas the InVu bracket had a statistically lower maximum frictional force. This showed that saliva produced some changes in the frictional coefficients, as suggested by Saunders and Kusy, ${ }^{29}$ who said that saliva composition, nature, and especially its (natural or artificial) viscosity would be extremely important in explaining divergences in the frictional coefficients found in different studies. With natural saliva wet setting tests, they demonstrated similar frictional coefficients for both monocrystalline and polycrystalline brackets, thus corroborating the results found in this study for Radiance and 20/40 brackets.

Similar to the results found for Radiance and $\mathrm{InVu}$ brackets in this study, Sadique et $\mathrm{al}^{28}$ observed that in the presence of artificial saliva, sapphire monocrystalline brackets had higher frictional forces compared to metal and ceramic brackets (conventional or with metal slots) in sliding mechanics over stainless steel wires and elastomeric ligature.

Kusy, Whitley and Prewitt ${ }^{18}$ observed that in artificial and natural saliva studies, saliva could behave as lubrication or adherence, and this would change according to the type of archwire used. These authors, together with Pratten et $\mathrm{al}^{24}$ and Sadique et $\mathrm{al},{ }^{28}$ noticed that by using stainless steel orthodontic wires, saliva would produce an adherence effect and, thus, significantly increase the frictional coefficient, corroborating the results found in this study regarding 20/40 and $\mathrm{InVu}$ polycrystalline brackets. For monocrystalline brackets, however, this relation was not found, as demonstrated by Saunders and Kusy, ${ }^{29}$ suggesting that wire composition might not be the only variable related to an increased frictional coefficient.

Tseleps, Brockhurst and West, ${ }^{34}$ in contrast, emphasized that artificial saliva would promote a lubrication effect in sliding mechanics for monocrystalline and polycrystalline brackets over stainless steel wires, thus significantly reducing the frictional coefficient. When beta-titanium wires were used, however, they observed a significant increase in the coefficient. Saunders and Kusy ${ }^{29}$ reported a decrease in the frictional coefficient for monocrystalline brackets in the presence of natural saliva in sliding mechanics over titanium-compounded wires. This decreased friction was attributed to the formation of a smear layer on the slots in these brackets when using these ligatures.

For these authors, ${ }^{29}$ saliva is a factor that caused several divergences among results as a function of its (natural or artificial) composition, viscosity, and even delivery technique, and it can increase, decrease or not alter the frictional force. This divergence corroborates the results found in this study because frictional force increased in the presence of artificial saliva gel for polycrystalline brackets, whereas for monocrystalline brackets the force remained unchanged. 
Based on the results found in this study, new investigations are needed in dry and wet settings using other commercial brands of monocrystalline and polycrystalline esthetic brackets in an effort to scientifically prove which material would provide a better next-to-optimal force system based on a low frictional coefficient associated with favorable esthetics and a cost compatible with its utilization.

\section{CONCLUSIONS}

1. Radiance monocrystalline brackets, as tested in the absence of saliva, had statistically higher frictional coefficients, followed by the 20/40, and the $\mathrm{InVu}$ brackets, respectively.
2. For tests in the presence of an artificial saliva gel, Radiance bracket frictional coefficients were similar to those for the 20/40 and statistically higher for the InVu brackets.

3. Artificial saliva gel did not cause any significant changes in the maximum frictional forces for Radiance brackets. However, there was a significant increase in the frictional forces for the 20/40 and InVu brackets.

4. InVu brackets had the lowest frictional coefficients of all tested brackets, both for tests in the presence and absence of saliva. 


\section{REFERENCES}

1. Angolkar PV, Kapila S, Duncanson Jr MG, Nanda RS. Evaluation of friction between ceramic brackets and orthodontic wires of four alloys. Am J Orthod. 1990:98(6):499-506

2. Baccetti T, Franchi L, Camporesi M. Forces in the presence of ceramic versus stainless steel brackets with unconventional vs conventional ligatures. Angle Orthod. 2008;78(1):120-4.

3. Bággio E, Telles CS, Domiciano JB. Avaliação do atrito produzido por braquetes cerâmicos e de aço inoxidável, quando combinados com fios de aço inoxidável. Rev Dental Press Ortod Ortop Facial. 2007:12(1):67-77.

4. Bazakidou E, Nanda RS, Duncanson MQ, Sinha P. Evaluation of frictional resistance in esthetic brackets. Am J Orthod Dentofacial Orthop. 1997:112(2):138-44

5. Bednar JR, Gruendeman GW, Sandrik JL. A Comparative study of frictional forces. Am J Orthod Dentofacial Orthop. 1991;100(6):513-22.

6. Begg PR. Diferencial force in orthodontic treatment. Am J Orthod 1956;42(7):481-510

7. Bishara SE. Ceramic brackets and the need to develop national standards. Am J Orthod Dentofacial Orthop. 2000:117(5):595-7.

8. Burrow SJ. Friction and resistance to sliding in orthodontics: a critical review. Am J Orthod Dentofacial Orthop. 2009:135(4):442-7.

9. Cacciafesta V, Sfondrini MF, Scribante A, Klersy C, Auricchio F. Evaluation of friction of conventional and metal-insert ceramic brackets in various bracket-archwire combinations. Am J Orthod Dentofacial Orthop 2003:124(4):403-9.

10. Cha JY, Kim KS, Hwang CJ. Friction of convencional and silica-insert ceramic brackets in various bracket-wire combinations. Angle Orthod 2007:77(1):100-7

11. De Franco D, Spiller RE, Von Fraunhofer JA. Frictional resistances using teflon-coated ligatures with various bracket-archwire combinations. Angle Orthod. 1995;65(1):63-72

12. Doshi $\cup H$, Bhad-Patil WA. Static frictional force and surface roughness of various bracket and wire combinations. Am J Orthod Dentofacial Orthop 2011:139(1):74-9

13. Drescher D, Bourauel C, Schumacher $\mathrm{H}$. Frictional forces between bracket and arch wire. Am J Orthod Dentofacial Orthop. 1989:96(5):397-404

14. Fidalgo TK, Pithon MM, Maciel JV, Bolognese AM. Friction between different wire bracket combinations in artificial saliva - an in vitro evaluation. J Appl Oral Sci. 2011;19(1):57-62

15. Karamouzos A, Athanasiou AE, Papadopoulos MA. Clinical characteristics and properties of ceramic brackets: a comprehensive review. Am J Orthod Dentofacial Orthop. 1997:112(1):34-40

16. Keith O, Kusy RP, Witley JQ. Zirconia brackets: an evaluation of Morphology and coefficients of friction. Am J Orthod Dentofacial Orthop. 1994;106(6):605-14

17. Kusy RP, Whitley JQ. Coefficients of friction for arch wires in satinless steel and polycrystalline alumina bracket slots. Am J Orthod Dentofacial Orthop. 1990:98(4):300-12

18. Kusy RP, Whitley JQ. Prewitt MJ. Comparison of the frictional coefficients for selected archwire-bracket slot combinations in the dry and wet states. Angle Orthod. 1991:61(4):293-302.
19. Kusy RP. A review of contemporary archwires: their properties and characteristics. Angle Orthod. 1997;67(3):197-207.

20. Kusy RP. The future of orthodontic materials: the long-term view. Am J Orthod Dentofacial Orthop. 1998;113(1):91-5.

21. Loftus BP, Artun J, Nicholis JI, Alonzo TA, Stoner JA. Evaluation of friction during sliding tooth movement in various bracket-arch wire combinations. Am J Orthod Dentofacial Orthop. 1999;116(3):336-45.

22. Matarese G, Nucera R, Militi A, Mazza M, Portelli M, Festa F, et al. Evaluation of frictional forces during dental alignment: an experimental model with 3 nonleveled brackets. Am J Orthod Dentofacial Orthop. 2008:133(5):708-15

23. Nishio C, Motta AFJ, Elias CN, Mucha N. In vitro evaluation of frictional forces between archwires and ceramic brackets. Am J Orthod Dentofacial Orthop. 2004;125(1):56-64

24. Pratten DH, Popli K, Germane N, Gunsolley JC. Frictional resistance of ceramic and stainless steel orthodontic brackets. Am J Orthod Dentofacial Orthop. 1990;98(5):398-403.

25. Prososki RR, Bagby MD, Erickson LC. Static frictional force and surface roughness of nickel-titanium arch wires. Am J Orthod Dentofacial Orthop. 1991:100(4):341-8

26. Reicheneder CA, Baumert U, Gedrange T, Proff P, Faltermeier A Muessig D. Frictional properties of aesthetic brackets. Eur J Orthod. 2007:29(4):359-65

27. Rueggeberg FA, Lockwood PE. Thermal debracketing of single cristal sapphire brackets. Angle Orthod. 1992;62(1):45-50

28. Sadique SE, Ramakrishna S, Batchelor AW, Bing CH. In vitro frictional behavior and wear patterns between contemporary and aesthetic composite orthodontic brackets and archwires. Wear. 2006;261:1121-39.

29. Saunders CR, Kusy RP. Surface topography and frictional characteristics of ceramic brackets. Am J Orthod Dentofacial Orthop. 1994;106(1):76-87

30. Stoner MM. Force control in clinical practice: an analysis of forces currently used in orthodontic practice and a description of new methods of contouring loops to obtain effective control in all three planes of space. Am J Orthod. 1960;46(3):163-86.

31. Tanne K, Matsubara S, Shibaguchi T, Sakuda M. Wire friction from ceramic brackets during simulated canine retraction. Angle Orthod. 1991;61(4):285-90

32. Taylor NG, Isson K. Frictional resistance between orthodontic brackets and archwires in the bucal segments. Angle Orthod. 1996:66(3):215-22

33. Tecco S, Festa F, Caputi S, Traini T, Di Lorio D, D'Attilio M. Friction of convencional and self-ligating brackets using a 10 bracket model. Angle Orthod. 2005;75(6):1041-5

34. Tselepis M, Brockhurst $P$, West $V$. The dynamic frictional resistance between orthodontic brackets and arch wires. Am J Orthod Dentofacial Orthop. 1994:106(2):131-8

35. Vaughan JL, Duncanson MG, Nanda RS, Currier F. Relative kinetic frictional forces between sintered stainless steel brackets and orthodontic wires. Am J Orthod Dentofacial Orthop. 1995:107(1):20-7. 